\title{
Potensi Hot Water Extract Rumput Laut Caulerpa sp. dan Sargassum Sebagai Komponen Immunonutrisi Pada Budidaya Udang Vannamei (Litopenaeus vanamei)
}

\author{
Subagiyo* dan Dyah Ismi Fatichah \\ Jurusan IImu Kelautan, Fakultas Perikanan dan IImu Kelautan, Universitas Diponegoro. \\ JI. Prof. Soedarto, SH. Kampus UNDIP Tembalang, Semarang 50275 \\ Email :subagiyo_kelautan@yahoo.co.id
}

\begin{abstract}
Abstrak
Immunonutisi adalah nutrient spesifik yang mampu memodulasi aktivitas sistem immun. Ada tiga target untuk immunonutrisi diantaranya adalah sistem pertahanan seluler. Pada udang sistem pertahanan seluler bertumpu pada aktivitas fagositosis hemosit. Pada penelitian ini dikaji potensi hot water extract rumput laut Caulerpa sp dan Sargassum sp sebagai immunonutrisi pada budidaya udang vanamei berdasarkan jumlah total dan aktivitas fagositosis hemosit udang vanamei. Percobaan telah dilakukan dengan cara memberi makan udang dengan pakan udang yang diperkaya dengan hot water extract rumput laut Caulerpa sp dan Sargassum sp. Ekstrak rumput laut diberikan pada konsentrasi 1 \% (10 g/kg pakan). Udang diberi pakan sebanyak $5 \%$ berat badan sehari yang diberikan dalam 3 kali pemberian pakan (pagi siang dan malam). Darah udang (hemolimfe) diambil setiap 4 hari sekai selama 2 minggu. Setiap kali pengambilan darah dilanjutkan dengan penghitungan jumlah total hemosit dan pengukuran aktivitas fagositosis hemosit. Data sekunder mengenai kandungan nutrisi dan komponen fungsional ekstrak Caulerpa dan Sargassum digunakan untuk mendukung hasil percobaan potensi rumput laut sebagai sumber immunonutrisi. Hasil penelitian menunjukan bahwa hot water extract rumput laut mempunyai potensi untuk dikembangkan sebagai sumber immunonutrisi untuk budidaya udang. Hal ini ditunjukan oleh percobaan pemberian pakan udang yang diperkaya dengan ekstrak Caulerpa sp dan Sargassum sp mampu meningkatkan jumlah total dan aktivitas fagositosis hemosit udang vanamei. Data sekunder menunjukan bahwa Caulerpa dan Sargassum kaya akan sulphated polysaccharide, asam amino esensial, mineral dan vitamin yang semuanya berperan dalam menstimulasi sistem immunitas.
\end{abstract}

Kata kunci : immunonutrisi, ekstrak rumput laut, sistem pertahanan seluler, udang vanamei

\section{PENDAHULUAN}

Serangan penyakit merupakan masalah utama yang dihadapi oleh para pembudidaya perikanan. Salah satu komponen pada konsep terjadinya penyakit, triangle diseases, adalah faktor hewan budidaya. Kharakteristik hewan budidaya yang penting dalam terjadinya penyakit adalah status daya tahan terhadap penyakit. yang dapat di pengaruhi oleh jenis nutrisi yang dikonsumsinya. Potensi untuk memodulasi aktivitas sistem immun melalui intervensi nutrien spesifik disebut sebagai immunonutrisi. Konsep ini diterapkan pada situsai pengubahan suplai nutrien untuk memodifikasi respon immun atau inflamatosri. Ada tiga target potensial immunonutrisi yaitu : fungsi barier mukosal, pertahanan seluler dan inflmasi lokal atau sistemik. Nutrient yang paling sering dikaji untuk immunonutrisi adalah arginine, glutamine, asam amino bercabang, n-3 fatty acids, dan nucleotides (Calder, 2003). $\omega-3$ PUFAs, minerals (seperti Zn dan $\mathrm{Se}$ ) serta bermacam-cama senyawa yang bersifat antioksidatif (Wichers, 2009). Selama ini immunonutrisi diterapkan pada bidang klinis yaitu pada pasien yang mengalami sakit yang kritis atau pasien bedah dengan tujuan to fortify hampered immune function Application routes can be either parenteral or enteral; the optimal 
route may depend on patient and disease characteristics. (Wichers, 2009).

Rumput laut merupakan sumberdaya laut yang potensial sebagai sumber fitokimia yang mempunyai aktifitas biologi yang bermanfaat bagi kesehatan, seperti carotenoids, phycobilins, fatty acids, polysaccharides, vitamins, sterols, tocopherol dan phycocyanins dan juga peptida bioaktif dengan fungsi biologis seperti antihypertension, immunomodulatory, antithrombotic, antioxidant, anticancer dan antimicrobial activities. Sampai saat ini sejumlah oligosakarida dengan aktivitas immunostimulant, antioksidan dan antitumor telah dikarakterisasi.

Salah satu karakteristik nutritif rumput laut adalah kandungan antioksidan yang tinggi (Lordan et al, 2011) Lebih jauh potensi rumput laut sebagai sumber bahan aktif telah direview oleh Lee (2008) dan Lordan et al (2011). Pada kajian potensi rumput laut sebagai sumber immunonutrisi pada budidaya perikanan dilakukan berdasarkan hasil penelitian menggunakan rumput laut Sargassum sp dan Caulerpa sp serta berdasarkan hasilhasil penelitian yang serupa yang telah dipublikasikan di jurnal ilmiah.

\section{MATERI DAN METODE}

Penelitian ini telah dilakukan di Balai Budidaya Air Payau Situbondo dengan metode eksperimental. Rumput laut Caulerpa sp diperoleh dari perairan pantai Teluk Awur, Jepara dan Sargassum $\mathrm{sp}$ diperoleh dari perairan Pantai Rembang. Sedangkan udang Vanamei diperoleh dari tambak komersial di daerah Situbondo, Jawa Timur.

\section{Ekstraksi rumput laut}

Rumput laut diekstraksi dengan teknik hot water extraction. Sebanyak $3 \mathrm{~kg}$ rumput laut dimasukan ke dalam 2 liter pelarut (akuades) kemudian dipanaskan hingga mendidih. Filtrasi dilakukan untuk memisahkan ampas (padatan yang tersisa). Filtrat yang diperoleh selanjutnya dilakukan evaporasi pelarut menggunakan rotavapor. Ekstrak yang diperoleh dalam bentuk pasta selanjutnya di kering bekukan dan dihancurkan hingga menjadi serbuk.

\section{Suplementasi Ekstrak Rumput Laut pada Pakan Udang}

Ekstrak Caulerpa sp.dan Sargassum sp. ditambahkan kedalam pakan buatan komersial udang (produksi Bintang) dengan dosis $1 \%$ (w/w). Prosedur suplementasi dilakukan sesuai dengan prosedur yang dikerjakan di laboratorium pakan buatan BBAP Situbondo.

\section{Eksperimen}

Percobaan untuk mengetahui potensi rumput laut sebagai sebagai imunonutrisi dilakukan dalam 3 tahap kegiatan yaitu aklimasi udang, percobaan pemberian pakan yang telah disuplementasi dengan ekstrak rumput laut, dan pengukuran parameter immunologi berdasarkan gambaran hematologi (jumlah total hemosit dan aktivitas fagsitosis).

\section{Aklimatisasi udang}

Udang vannamei dengan berat \pm 10 gram dipelihara dalam bak semen besar yang dilengkapi sistem aerasi dan sirkulasi air. Aklimatisasi dilakukan selama 15 hari. Selama proses aklimatisasi dilakukan pemberian pakan menggunakan pelet komersial.

\section{Percobaan}

Udang yang telah diaklimatisasi selanjutnya dibagi secara random ke dalam akuarium percobaan (Ukuran $60 \times 30 \times 40 \mathrm{~cm}$ ) dengan kepadatan 14 ekor per akuarium. Akuarium di set dengan aerasi (menggunakan 1 batu aerasi) dan sistem flow through dengan teknik pipa goyang (hasil rekayasa BBAP-Situbondo). Selama percobaan udang diberi pakan dengan pakan yang telah disuplementasi dengan ekstrak rumput laut. Pakan diberikan sebanyak $5 \%$ berat badan udang dalam 3 kali pemberian yaitu pagi, siang dan malam. 


\section{Analisis sistem pertahanan (immun) udang}

1. Pengambilan hemolimfe Hemolimfe udang sebanyak $0,3 \mathrm{ml}$ diambil menggunakan spuit $1 \mathrm{~mL}$ yang telah dibasahi dengan antikoagulan (EDTA 10\%). Pengambilan hemolimfe dilakukan pada bagian thorax antara kaki jalan dan kaki renang. Selanjutnya sampel hemolimfe ditampung dalam mikrotube yang bagian dalamnya telah dibasahi larutan antikoagulan.

2. Penghitungan Total Haemosit

Penghitungan total hemosit dilakukan menggunakan Neubaver Counting Chamberdan mikroskop dengan perbesaran 400X. Jumlah total hematosit dapat diketahui dengan rumus:

$\sum$ total hemosit $=\left(\sum\right.$ sel yang dihitung $\left.\times 4\right) \times 10^{4}$

3. Penghitungan Aktivitas Fagositosis

Hemolimfe sebanyak $100 \mu \mathrm{ll}$ dari mikrotube dicampur dengan 100 $\mu$ bakteri Vibrio alginolyticus yang telah dimatikan dengan formalinkemudian diinkubasi selama 20 menit. Sampel sebanyak $5 \mu \mathrm{l}$ diteteskan di atas objek glass dan dibuat preparat apusan selanjutnya difiksasi dengan ethanol $95 \%$, dan dilakukan pewarnaan dengan Safranin $0.15 \%$ Pengamatan dilakukan terhadap 100 sel menggunakan mikroskop cahaya pada perbesaran 400X. Selanjutnya dihitung jumlah sel dengan aktifitas fagositosis dan sel yang tidak beraktifitas fagositosis, dihitung pula jumlah selv. alginolyticus yang difagositosis tiap sel. Aktifitas Fagositosis (AF) dihitung dengan rumus:

$$
\begin{gathered}
A F(\%)=\left(\frac{\sum \text { fagosit yang aktif }}{\sum \text { fagosit yang diamati }} /\right) \times 100 \% \\
I P=\frac{\sum V \cdot \text { algino yang difagosit }}{\sum \text { sel fagosit yang diamati }}
\end{gathered}
$$

\section{HASIL DAN PEMBAHASAN}

Respon immunologis udang vanamei (jumlah total hemosit dan aktivitas fagositosis) terhadap aplikasi ekstrak rumput laut ditunjukan Tabel 1.

Berdasarkan hasil penelitian (Tabel 1) menunjukan bahwa pemberian ekstrak rumput laut berpengaruh terhadap parameter hematologi udang vanamei. Perlakuan pemberian ekstrak Caulerpa sp menyebabkan peningkatan jumlah total hemosit. Pada kondisi penelitian ini terjadi peningkatan jumlah total hemosit pada pengamatan minggu ke 2 aplikasi, sedangkan pada perlakuan pemberian ekstrak Sargassum sp terjadi pada pengamatan minggu ke 3. Pemberian ekstrak Caulerpa sp dam Sargassum sp juga meningkatan aktivitas fagositosis.

Pada kondisi penelitian ini peningkatan terjadi pada pengamatan minggu I. Jumlah total hemosit dan aktivitas fagositosis merupakan dua diantara parameter hematologi yang merupakan indikator sistem pertahanan tubuh seluler. Beberapa penelitian lain juga menunjukan hasil yang serupa bahwa aplikasi rumput laut baik dalam bentuk tepung, ekstrak, maupun senyawa tertentu yang merupakan komponen utama rumput laut menyebabkan peningkatan parameter immun ikan dan udang (Tabel 2). Hal ini menunjukan bahwa hot water extract rumput laut Sargassum dan Caulerpa mengandung senyawa nutritif yang meningkatkan status immun udang yang ditunjukan baik oleh peningkatan jumlah total hemosit maupun aktivitas fagositosis hemosit udang.

Menurut Wicher (2007) diet dan nutrisi dapat mempengaruhi berfungsinya bermacam-macam parameter immun. Komponen immunonutrisi diantaranya meliputi asam amino spesifik (biasanya glutamin dan arginin), nukleotida, PUFA $\omega$ 3, mineral (seperti Zn dan Se) serta bermacam-macam senyawa antioksidan. Penelitian yang lain terkait dengan penggunaan rumput laut untuk meningkatkan status immun udang juga ditunjukan oleh banyak peneliti (Tabel 1) 

Tabel 1. Hasil penghitungan parameter hematologi udang vannamei

\begin{tabular}{|c|c|c|c|c|c|c|c|c|c|}
\hline \multirow{3}{*}{$\begin{array}{l}\text { Parameter } \\
\text { Hematologi }\end{array}$} & \multicolumn{9}{|c|}{ Perlakuan } \\
\hline & \multicolumn{3}{|c|}{ Kontrol } & \multicolumn{3}{|c|}{ Caulerpa sp. } & \multicolumn{3}{|c|}{ Sargassum sp. } \\
\hline & $\begin{array}{l}\text { Hari } \\
\text { ke4 }\end{array}$ & $\begin{array}{l}\text { Hari } \\
\text { ke8 }\end{array}$ & $\begin{array}{l}\text { Hari } \\
\text { ke12 }\end{array}$ & $\begin{array}{l}\text { Hari } \\
\text { ke4 }\end{array}$ & $\begin{array}{l}\text { Hari } \\
\text { ke8 }\end{array}$ & $\begin{array}{l}\text { Hari } \\
\text { kel2 }\end{array}$ & $\begin{array}{l}\text { Hari } \\
\text { ke4 }\end{array}$ & $\begin{array}{l}\text { Hari } \\
\text { ke8 }\end{array}$ & $\begin{array}{l}\text { Hari } \\
\text { kel2 }\end{array}$ \\
\hline $\begin{array}{l}\text { Total Haemosit (sel/l) } \\
\qquad\left(\begin{array}{cl}\left.1^{7}\right)\end{array}\right.\end{array}$ & $\begin{array}{c}2,43 \\
\pm \\
1,21 \\
\end{array}$ & $\begin{array}{c}0,568 \\
\pm \\
0,28\end{array}$ & $\begin{array}{c}1,62 \\
\pm \\
1,28 \\
\end{array}$ & $\begin{array}{c}0,63 \\
\pm \\
0,37 \\
\end{array}$ & $\begin{array}{c}4,69 \\
\pm \\
4,69 \\
\end{array}$ & $\begin{array}{c}1,18 \\
\pm \\
1,18\end{array}$ & $\begin{array}{c}0,57 \\
\pm \\
0,05 \\
\end{array}$ & $\begin{array}{c}1,298 \\
\pm \\
1,3 \\
\end{array}$ & $\begin{array}{c}4,63 \\
\pm \\
3,92 \\
\end{array}$ \\
\hline \multicolumn{10}{|l|}{ Fagositosis } \\
\hline $\mathrm{PI}$ & $\begin{array}{c}5,39 \\
\pm \\
2,81\end{array}$ & $\begin{array}{c}2,55 \\
\pm \\
1,53\end{array}$ & $\begin{array}{c}5,51 \\
\pm \\
0,61\end{array}$ & $\begin{array}{c}1,4 \\
\pm \\
0,19\end{array}$ & $\begin{array}{c}6,09 \\
\pm \\
2,03\end{array}$ & $\begin{array}{c}5,75 \\
\pm \\
0,18\end{array}$ & $\begin{array}{c}1,63 \\
\pm \\
0,40\end{array}$ & $\begin{array}{c}5,15 \\
\pm \\
0,35\end{array}$ & $\begin{array}{c}7,49 \\
\pm \\
0,68\end{array}$ \\
\hline PA (\%) & $\begin{array}{c}22,31 \\
\pm \\
10,9\end{array}$ & $\begin{array}{c}44,80 \\
\pm \\
33,83\end{array}$ & $\begin{array}{c}19,86 \\
\pm \\
2,38\end{array}$ & $\begin{array}{c}73,95 \\
\pm \\
8,05\end{array}$ & $\begin{array}{c}20,82 \\
\pm \\
10,5\end{array}$ & $\begin{array}{c}20,03 \\
\pm \\
0,66\end{array}$ & $\begin{array}{c}64,33 \\
\pm \\
16,16\end{array}$ & $\begin{array}{c}23,27 \\
\pm \\
3,15\end{array}$ & $\begin{array}{c}13,57 \\
\pm \\
1,12\end{array}$ \\
\hline
\end{tabular}

Keterangan: - nilai adalah rata - rata \pm standar deviasi $(n=3)$.

Respon immunologis merupakan suatu proses yang kompleks yang merupakan interaksi dari berbagai proses fisiologi yang lain. Menurut Satyaraj (2011) Nutrisi dan sistem immun berinteraksi pada berbagai tingkatan, yang secara sederhana dapat dibedakan menjadi 4 tingkatan. Tingkat I dan II merupakan interaksi yang bersifat pasif sedangkan tingkat III dan IV merupakan interaksi yang terjadi melalui modifikasi respon immun menggunakan agensia seperti IRMs yang memiliki target utama reseptor PAMP. Pada tingkat I berfokus pada energi makanan, protein, vitamin ( $A, C$ dan $E$ ) dan mineral seperti $\mathrm{Zn}, \mathrm{Mg}, \mathrm{Fe}$, dan lainlain.Mineral $\mathrm{Ca}$ dan $\mathrm{Mg}$ berperan pada mekanisme signaling pada sistem immun sehingga penting untuk meningkatkan respon immun.

Pada tingkat II meliputi pengoptimalan nutrien kunci (baik makro maupun mikronutrien yang penting bagi sel-sel immun. Sistem immun membutuhkan nutrien tertentu dan penyediaan dalam jumlah yang lebih besar akan mengoptimalkan fungsi immun. Defisiensi nutrien kunci ini berakibat negatif pada sistem immun. Protein pada level dan kualitas yang lebih tinggi dalam diet diperlukan untuk sistem immun. Pada tingkat molekular protein merupakan komponen struktural dan memediasi proses kunci sistem immun.
Reseptor, Ig, komponen komplemen dan protein bakterisidal semuanya adalah protein. Pada tingkat III adalah modulasi aktif sistem immun. Pada tingkat ini menekankan pada interaksi dengan sistem imun untuk memodulasi fungsinya.Pada tingkat IV adalah nutrisi personal. Interaksi antara diet, lingkungan dan genom menentukan status kesehatan dan mempengaruhi penyakit kronis. Beberapa hasil penelitian yang merujuk pada Sargassum dan Caulerpa sebagai sumber nutrisi yang mampu membangkitkan system imun ditunjukan oleh penelitian Handayani, et al. (2004) mengenai komposisi nutrisi rumput laut $S$. crassifolium , Ratana-arporn \& Chirapar (2006) mengenai komposisi nutrisi rumput laut C. Lentillifera, Abou-El-Wafa, et al. (2011)mengenai profil asam amino $S$. subrepandum dan Valerie et al., 1999 dalam Ratana-arporn \& Chirapar (2006) mengenai profil asam amino C. Lentillifera, Costa, et al, 2011, mengenai aktivitas antioksidan ekstrak S.crassifolia dan Rodrigues et al. (2013) mengenai aktivitas antioksidan ekstrak C. taxifolia

\section{KESIMPULAN}

Berdasarkan hasil penelitian dan kajian pustaka (hasil penelitian serupa) menunjukan bahwa rumput laut sangat potensial untuk dikembangkan sebagai 
Tabel 2. Hasil-hasil penelitian efek pemberian rumput laut terhadap sistem pertahanan non spesifik udang

\begin{tabular}{|c|c|c|}
\hline $\begin{array}{l}\text { Jenis komponen } \\
\text { rumput laut }\end{array}$ & Efek pada sistem pertahanan & Referensi \\
\hline Asam alginat & $\begin{array}{l}\text { Pada ikan karper (Cyprinus carpio L.), sodium } \\
\text { alginate meningkatkan aktivitas fagositosis }\end{array}$ & $\begin{array}{l}\text { Fujiki and Yano, (1997) } \\
\text { cit Ahmadifar, et al, } \\
\text { (2009) }\end{array}$ \\
\hline Asam alginat & $\begin{array}{l}\text { Pada Snakehead (Channa striata) injeksi asam } \\
\text { alginat meningkatkan jumlah neutrofil, tingkat } \\
\text { fagositosis, dan respiratory burst activity }\end{array}$ & $\begin{array}{l}\text { Peddie et al, (2002) } \\
\text { cit. Ahmadifar, et al, } \\
\text { (2009) }\end{array}$ \\
\hline $\begin{array}{l}\text { crude fucoidan (CF) } \\
\text { Sargassum polycystum }\end{array}$ & $\begin{array}{l}\text { Menurunkan dampak infeksi White Spot } \\
\text { Syndrome virus (WSSV) pada Penaeus } \\
\text { monodon, crude fucoidanmenghambat } \\
\text { pertumbuhan Vibrio harveyi, Staphylococcus } \\
\text { aureus dan Escherichia coli dengan minimal } \\
\text { inhibition concentrations (MIC) sebesar } 12.0 \text {, } \\
12.0 \text { dan } 6.0 \mathrm{mg} / \mathrm{ml} \text {. }\end{array}$ & Chotigeat, et al, 2004 \\
\hline $\begin{array}{l}\text { Ekstrak butanol Ulva } \\
\text { lactuca (T5) dan } \\
\text { Sargassum wightii (T6). }\end{array}$ & $\begin{array}{l}\text { Meningkatkan survival rate }(43.32-58.88 \%) \\
\text { laju pertumbuhan spesifik }(1.46-2.15 \%) \text { dan } \\
\text { menurunkan beban V. parahaemolyticus load } \\
\text { (1.36-2.03 dan } 1.47-2.16 \times 10^{5} \text { CFU g } \text { g }^{-1} \text { berturut- } \\
\text { turut pada jaringan otot dan hepatopancreas } \\
\text { tissues) }\end{array}$ & Immanuel, et al, 2004 \\
\hline $\begin{array}{l}\text { Ekstrak polisakarida } \\
\text { Sargassum fusiforme }\end{array}$ & $\begin{array}{l}\text { Total hemosit count meningkat seiring dengan } \\
\text { meningkatnya dosis SFPSE. Konsnetrasi protein } \\
\text { dan aktivitas PO pada hemolimfe udang pada } \\
\text { awalnya meningkat kemudian menurun seiring } \\
\text { dengan meningkatnya dosis SFPSE. AKtivitas } \\
\text { SOD tidak terpengaruh secara nyata oleh } \\
\text { aplikasi SFPSE }\end{array}$ & Huang, et al, 2006 \\
\hline $\begin{array}{l}\text { hot-water extract } \\
\text { brown seaweed } \\
\text { Sargassum duplicatum }\end{array}$ & $\begin{array}{l}\text { Meningkatkan total haemocyte count (THC), } \\
\text { phenoloxidase activity, respiratory burst, } \\
\text { aktivitas fagositosis }\end{array}$ & Yeh, et al, 2006 \\
\hline $\begin{array}{l}\text { Powder dan hot-water } \\
\text { extract Sargassum } \\
\text { hemiphyllum var. } \\
\text { chinense }\end{array}$ & $\begin{array}{l}\text { Meningkatkab jumlah total hemosit, aktivitas } \\
\text { PO, respiratory burst, dan aktivitas lysozyme } \\
\text { udang vannamei setelah diperlakukan dengan } \\
\text { perendaman dalam air laut yang } \\
\text { mengandung serbuk atau ekstrak rumput laut. }\end{array}$ & Huynh, et al, 2011 \\
\hline $\begin{array}{l}\text { Ulva lactuca dan } \\
\text { Spyridia filamentosa }\end{array}$ & $\begin{array}{l}\text { Menurunkan total hemocyte counts (THC), } \\
\text { tidak ada efek yang diamati phagocytosis, } \\
\text { phenoloxidase pada abalone hemolymph }\end{array}$ & Dang, et al, 2011 \\
\hline $\begin{array}{l}\text { hot-water extract } \\
\text { Sargassum } \\
\text { glaucescens }\end{array}$ & $\begin{array}{l}\text { Meningkatkan total haemocyte count (THC), } \\
\text { differential haemocyte count (DHC), total } \\
\text { plasma protein (TPP), Phagocytic activity (PA), } \\
\text { bacterial clearance efficiency (BCE) dan } \\
\text { bactericidal activity (BE) pada F. indicus yang } \\
\text { direndam dalam air laut yang mengnadung } \\
\text { hot-water extracts Sargassum glaucescens at } \\
100,300 \text { and } 500 \mathrm{mg} / \mathrm{l} \text {. }\end{array}$ & Ghaednia, et al, 2011 \\
\hline $\begin{array}{l}\text { Fucoidan dari } \\
\text { Sargassum wightii }\end{array}$ & $\begin{array}{l}\text { Meningkatkan THC, aktivitas prophenoloxidase } \\
\text {, aktivitas respiratory burst, aktivitas superoxide } \\
\text { dismutase dan aktivitas fagositosis pada } \\
\text { udang windu (Penaeus monodon) }\end{array}$ & Immanuel, et al, 2012 \\
\hline
\end{tabular}


komponen immunonutrisi khususnya dalam mendukung strategi pengendalian penyakit secara terpadu berbasis peningkatan status sistem pertahanan seluler pada budidaya udang.

\section{DAFTAR PUSTAKA}

Ahmadifar, E., Gh. A. Takami, M. Sudagar, 2009, Growth Performance, Survival and Immunostimulation, of Beluga (Huso huso) Juvenile Following Dietary Administration of Alginic Acid (Ergosan), Pakistan Journal of Nutrition, $8: 227-232$

Al-Amoudi, O. A., H. H. Mutawie, A.V. Patel , G. Blunden, 2009,Chemical composition and antioxidant activities of Jeddah corniche algae Saudi Arabia, Saudi Journal of Biological Sciences 16, 23-29

Amna, T., J. Ara, V. Sultana, S. E. Ehteshamul-Haque, M. Athar, 2011, Antioxidant potential of seaweeds occuring at Karachi coast of pakistan, J. of Applied Botany and food Quality 84: 207-212.

Calder, P. C., 2003, Immunonutrition, BMJ 327;117-118

Costa, L. S. , G. P. Fidelis ., C. B. S. Telles, N. Dantas-Santos , R. B. G. Camara, S. L. Cordeiro ., M. S. S. P. Costa, J. Almeida-Lima, R. F. Melo-Silveira, R. M. Oliveira , I. R. L. Albuquerque , G. P.V. Andrade and H. A.O. Rocha, 2011, Antioxidant and Antiproliferative Activities of Heterofucans from the Seaweed Sargassum filipendula, Mar. Drugs , 9, 952-966

Ghada S. E. Abou-El-Wafaa, Khaled A. Shaabanb, Mohamed E. E. ElNaggara, Mohamed Shaaban, 2011, Bioactive constituents and Biochemical Composition of the Egiptian Brown Algae Sargassum subrepandum (Forsk), Rev. Latinoamer. Quím. 39 :62-74

Ghaednia B., M. R. Mehrabi, M. Mirbakhsh, V. Yeganeh, P. Hoseinkhezri, G. Garibi, G. Jabbari A, 2011, Effect of hot-water extract of brown seaweed Sargassum glaucescens via immersion route on immune responses of Fenneropenaeus indicus,
Iranian Journal of Fisheries Sciences, 10: 616-630

Handayani, T., Sutarno, A.D. Setyawan, 2004, Analisis Komposisi Nutrisi Rumput Laut Sargassum crassifolium J. Agardh., Biofarmasi 2 (2): 45-52

Lee, B., 2008, Seaweed: Potential as a marine vegetable and other opportunities, Rural Industries Research and Development Corporation. Gymea Australia.

Lordan, S., R. P. Ross and C. Stanton, 2011, Marine Bioactives as Functional Food Ingredients: Potential to Reduce the Incidence of Chronic Diseases, Mar. Drugs $9: 1056-1100$

Ratana-arporn, P., A. Chirapart, 2006, Nutritional Evaluation of Tropical Green Seaweeds Caulerpa lentillifera and Ulva reticulata, Kasetsart J. (Nat. Sci.) 40: $75-83$

Redmond, H.P., P. P. Stapleton, P. Neary, D. Bouhier-Hayes, 1998, Immunonutrition: The Role of Taurine, Nutrition 14:7/8,

Robledo, D., Y.F. Pelegrin, 1997, Chemical and Mineral Composition of Six Edible Seaweed Species of Yucatan, Botanica Marina 40: 301-306

Rodrigues, J.A.G., E.S.O. Vanderlei, A. L.G.Quinderé, V. S. Monteiro, S. M. M. Vasconcelos, N. M. B. Benevides, 2013, Antinociceptive activity and acute toxicological study of a novel sulfated polysaccharide from from Caulerpa cupressoides var. Lycopodium (Chlorophyta) in Swiss mice, Acta Scientiarum. Technology Maringá, 35:417-425.

Satyaraj, E, 2011, Emerging Paradigms in Immunonutrition, Topics in Companion Animal Medicine 26:2532

Tariq, A., J.A. Sultana, S.Ehteshamul-Haque, M. Athar, 2011, Antioxidant potential of seaweed occuring at Karachi coast of Pakistan, Jounal of applied Botany and Food Quality 84:207-212

Vanderhoof, J. A., 1998, Immunonutrition: The Role of Carbohydrates, Nutrition $14: 7 / 8$

Wichers, H, 2009, Immunomodulation by food: promising conceptfor mitigating allergic disease, Anal Bioanal Chem 395:37-45 